\title{
T-cell receptor chain Vbeta subunit staining to quantify the malignant clone in adult T-cell leukemia
}

\author{
Aileen G Rowan ${ }^{1 *}$, Paul Fields², Graham P Taylor ${ }^{1}$, Charles RM Bangham ${ }^{1}$ \\ From 17th International Conference on Human Retroviruses: HTLV and Related Viruses \\ Trois Ilets, Martinique. 18-21 June 2015
}

Adult T cell leukemia (ATL) is typically characterised by expansion of a single dominant malignantly transformed HTLV-1-infected clone. Clinically, the abundance of this clone can be estimated by flow cytometric assessment of CD4, CD25 and CD7 expression, and, more recently, by quantitative LM-PCR analysis of viral integration site. In addition to the unique proviral integration site, malignant clones arising from a single infection event also share an identical T cell receptor (TCR) sequence, utilising one of a potential 47 TCR Vbeta subunit genes. Using multiparametric flow cytometry, we quantified the frequency of peripheral $\mathrm{T}$ cells bearing each of $24 \mathrm{TCR}$ Vbeta subunits in a cohort of individuals with adult $\mathrm{T}$ cell leukemia or lymphoma $(\mathrm{n}=26)$ at various stages of disease progression/remission. To establish an appropriate baseline, we also analysed $\mathrm{T}$ cells from asymptomatic carriers $(\mathrm{n}=11)$ and donors with HAM/TSP $(\mathrm{n}=13)$. Vbeta-specific antibodies stained $75 \%$ of CD3+ cells in donors without malignancy, and the median size of the largest single subset (CD4+Vbeta2+) was $7.6 \%$ of $\mathrm{CD} 3+$ cells. We detected putative $\mathrm{T}$ cell clones which exceeded $20 \%$ of CD3+ T cells only in individuals with active chronic or acute leukemia $(n=17)$, reaching frequencies of up to $96 \%$ of CD3+ T cells. With this method, we quantified the expression on clonally expanded populations of the putative ATL cell markers CD25, CCR4, TSLC1, CD7 and CD127. Almost 1\% of expanded clonal populations in ATL patients were CCR4+TSLC1+CD7-. Surprisingly, in most donors only $60 \%$ of the dominant clonal population expressed high levels of CD25. This flow cytometric protocol is a potentially powerful method to both monitor disease

\footnotetext{
* Correspondence: a.rowan@imperial.ac.uk

'Section of Virology, Department of Medicine, Imperial College London, UK Full list of author information is available at the end of the article
}

progression and response to therapy, providing fast and accurate quantification of clonally expanded populations. We are currently employing this technique to assay lysis of expanded clones by autologous cytotoxic $\mathrm{T}$ lymphocytes in patients with ATL.

\section{Authors' details}

${ }^{1}$ Section of Virology, Department of Medicine, Imperial College London, UK. 2Guy's and St Thomas' Hospital, London, UK.

Published: 28 August 2015

doi:10.1186/1742-4690-12-S1-P45

Cite this article as: Rowan et al.: T-cell receptor chain Vbeta subunit staining to quantify the malignant clone in adult T-cell leukemia. Retrovirology 2015 12(Suppl 1):P45.

Submit your next manuscript to BioMed Central and take full advantage of:

- Convenient online submission

- Thorough peer review

- No space constraints or color figure charges

- Immediate publication on acceptance

- Inclusion in PubMed, CAS, Scopus and Google Scholar

- Research which is freely available for redistribution

Submit your manuscript at www.biomedcentral.com/submit
() Biomed Central 